$\Leftrightarrow$

Revista ASPAS

ppgac - USP

\title{
O AFRO-CONTEMPORÂNEO NAS ARTES CÊNICAS: REFLEXÕES \\ METODOLÓGICAS \\ DE PESQUISA E \\ CRIAÇÃO NO CONTEXTO PÓS-COLONIAL
}

Editorial

Danilo Silveira

Daiana Felix Pereira (Dáda Felix) 
A revista Aspas é um periódico produzido pelos discentes do Programa de Pós-Graduação em Artes Cênicas (PPGAC) da Escola de Comunicações e Artes da Universidade de São Paulo (ECA-USP) que, em seu sistema de ideias, busca construir um diálogo reflexivo sobre o fazer e o pensar a arte da cena como questionamento, expansão e disseminação de informação. Por esse viés, a revista Aspas vem em suas últimas publicações problematizando os motes provenientes dos processos metodológicos nas artes cênicas e como esses processos se tornam construção de conhecimento.

A contribuição elegida para este número 7.1 se encontra com temas que emergem da discussão sobre a identidade étnico-racial de matriz africana e a inserção das artes cênicas no contexto desse axioma que, felizmente, tem ganhado espaço nas reflexões da atualidade. Dessa forma, as publicações que compõem o escopo desta edição pretendem pensar sobre processos e metodologias criados no campo da prática artística e do ensino das artes cênicas a partir do diálogo com referências culturais de matriz africana, com base em uma perspectiva pós-colonial de produção do conhecimento.

Portanto, a edição está pautada pelas seguintes perguntas: Como pensar novos modos de transmitir e mediar linguagens artísticas em relação a questões étnico-raciais? Que outras perspectivas podem ser pensadas para além de uma narrativa centrada na relação eu-outro orientada por uma referência europeia no fazer artístico? De que maneira tais perspectivas podem ser incorporadas no âmbito pedagógico e criativo das artes cênicas?

Ao pensar sobre as tradições de origem africana, Leda Maria Martins se refere à cultura negra como uma cultura das encruzilhadas, em que criação e conhecimento estão como um instante de potencialidade e de resistência. Para Martins,

\footnotetext{
A história dos negros nas Américas escreve-se numa narrativa de migrações e travessias, nas quais a vivência do sagrado, de modo singular, constitui um índice de resistência cultural e de sobrevivência étnica, política e social. (MARTINS, 1997, p. 24)
}

Martins postula que as tradições africanas, que nas Américas estiveram transpassadas, compõem um corpo em que as ancestralidades se fizeram 
presentes e potentes. Reconhecer, reafirmar e assinar nos corpos cênicos a presença dessas ancestralidades tornam-se, na era contemporânea, uma urgência que emerge das deficiências no que diz respeito às criações e pensamentos sobre as artes cênicas.

Partindo então da ideia de que o corpo negro que habita a arte da cena é uma presença potente para a permanência de um discurso político, trazemos em nossa seção Especial, para abrilhantar essa discussão, os textos das pesquisadoras convidadas professora doutora Inaicyra Falcão dos Santos e professora doutora Nadir Nóbrega Oliveira.

Inaicyra Falcão, professora livre-docente do Instituto de Artes da Universidade Estadual de Campinas (Unicamp), vem abordar tais questões apresentadas neste número sob o ponto de vista da dança afro em relação às ideias de Corpo e Ancestralidade como possibilidade de pesquisa e criação nas artes cênicas. Falcão desenvolve em seu texto o pensamento relacional entre a arte e a tradição afro-brasileira, construindo um diálogo que se pauta na linguagem artística da dança afro como comunicação intercultural na era contemporânea.

Contribuindo com o tema, Nadir Nóbrega Oliveira, professora adjunta do curso de licenciatura em Dança da Universidade Federal de Alagoas (UFAL) e diretora do Museu Théo Brandão de Antropologia e Folclore, propõe uma discussão que visa partilhar seu processo de criação com coreógrafos nos blocos afro-carnavalescos, além de um dizer sobre os teores da dança moderna e de danças africanas que vivenciou enquanto bailarina.

Na seção Artigos, propomos um olhar diversificado sobre tais questões, tão bem apresentadas pelos textos que as contemplam. Aqui poderemos ver contextualizações históricas, relatos empíricos, dizeres relacionais e análises de processos criativos que trazem a presença do corpo negro atuante na cena.

No texto de Mariana Soutto Mayor deparamos com uma preciosa discussão que busca elencar questões relacionadas às formas da presença dos negros e mestiços na festividade religiosa Triunfo Eucarístico, em Minas Gerais. Régia Mabel Freitas investiga a militância cênica no teatro negro brasileiro como meio de resistência e difusor de demandas da negritude. Monilson dos Santos Pinto, por sua vez, ao discutir sobre a temática do "nego fugido", 
discorre sobre as expressões populares da cultura brasileira e da ciência hegemônica acadêmica por meio do teatro didático brechtiano.

Dando continuidade à seção, a autora Adriana Miranda da Cunha expõe o processo criativo, social e político do Teatro Hillbrow, atuante em Johannesburgo, África do Sul. Sobre processos criativos, Altemar Di Monteiro também levanta uma discussão a partir do espetáculo $O$ jardim das flores de plástico - Ato 3: por baixo do saco preto, da Cia. Nóis de Teatro, na periferia de Fortaleza (CE), buscando pensar sobre os cruzamentos poéticos e políticos do teatro produzido pelos artistas negros do grupo na tessitura de rearranjos sobre o discurso hegemônico de cidade. $\mathrm{O}$ autor Elton Soares Siqueira investiga os artifícios estéticos e metodológicos que, no espetáculo Ombela do grupo pernambucano O Poste Soluções Luminosas, colaboraram para proclamar em cena a ancestralidade africana. Já Daiana de Moura, por meio do fluxo da análise cênica da obra Cunhãntã, trata da metodologia de investigação cênica e de sua presença como mulher negra na arte teatral. Contribuindo com os dizeres sobre processos criativos, Vanessa Soares dos Santos aborda a experiência cênica Querença, do Grupo Saramuná, obra inspirada nos conhecimentos da religiosidade afro-brasileira presente nas manifestações populares. Por fim, contribui com as discussões deste número o texto de Deise Santos Brito, que apresenta táticas de articulação arquitetadas a partir do deslocamento de artistas negras(os) na entrada do século $X X$.

Como estratégia de contribuição visual para as discussões apresentadas, teremos na seção Forma Livre o compartilhamento de fotos e imagens, fornecidas pelos autores dos artigos, que dialogam diretamente com os textos presentes nesta edição, incluindo fotos do espetáculo de dança Dikanga Calunga, da bailarina paulistana Kanzelumuka com o grupo Nave Gris Cia. Cênica.

Dado todo o material publicado nesta edição da revista Aspas, em que é problematizada a questão do afro-contemporâneo nas artes cênicas, buscamos apresentar aos leitores textos que deparam com e atualizam as questões sobre a prática do teatro que é criado, pensado e discutido por corpos negros. $\mathrm{O}$ afro-contemporâneo discutido nesta edição busca firmar a necessidade dessa voz, que por muitas vezes foi excluída. Assim, pensamos que este 
número surge por uma necessidade imediata e contribui para o fluxo positivo do pensamento que a cada momento vem sendo construído, na produção atual, sobre a presença do negro em cena.

Danilo Silveira e Daiana Felix Pereira (Dáda Felix) Editores do número

\section{Referências bibliográficas}

MARTINS, L. M. Afrografias da memória: o reinado do rosário no Jatobá. São Paulo; Belo Horizonte: Perspectiva; Mazza, 1997. 